Our thanks are due to Mr. F. Welch of this Institute for the photomicrographs.

${ }^{1}$ Jones, W. R., Ann. Trop. Med. and Parasit., 40, 130

"Wenyon, C. M., "Protozoology", 1 (Baillière, Tindall and Cox, London, 1926).

${ }^{3}$ Grassi, Atti a Societa ital. d. Scienze naturali, 24, 181 (1881). Quoted by Wenyon, ref. 4 .

- Wenyon, C. M., Archiv. für Protistenk., Suppl., 1, 169 (1907).

${ }^{5}$ Brug, S. L., Geneesk Tydschr. Med. Ned. Ind., 59, 577 (1919) (reviewed in Trop. Dis. Bull., 16, 8 (1920)).

- Kessel, J. F., Univ. Calif. Pub. Zoo., 20, 489 (1923).

Neal, R. A., Nature, 159, 502 (1947). Yorke, W., and Adams, A. R. D., Ann. Trop. Med. and Parasit.,
20, 279 (1926).

- Dobell, C., and Laidlaw, P. P., Parasit., 18, 283 (1926).

${ }^{10}$ Watson, J. M., Brit. Med. J., ii, 576 (Oct. 19, 1946).

\section{SCIENCE IN SOCIAL AFFAIRS}

$\mathrm{O}^{\mathrm{N}}$ $\mathrm{N}$ November 22, a conference of social scientists, convened by the Association of Scientific Workers, was held at Gas Industry House, London. The cinai): was taken by Mrs. W. Raphael, of the National Institute of Psychology, and the principal speakers were Prof. V. Gordon Childe and Mr. Roy Innes, general secretary of the Association.

The primary aim of the meeting was to enlist support for a draft report on "The Furtherance of the Social Sciences" prepared by a committee of the Association and shortly to be published. The meeting was the third of its kind, the first having been held in October 1945 to explore the interrelations between natural and social science, at which a Joint Sciences' Committee had been set up, and the second in December 1946 to consider the future of the social sciences. Sume months earlier, the Joint Sciences' Committee had been reconstituted as the National Committee on the Social Sciences of the Association. The conference was well attended by workers in the cognate social disciplines at universities, Government departments and research institutes.

In her opening remarks, the chairman observed that social scientists are becoming a distinct and self-conscious body of workers, which may be due partly to the unpopularity which they share, particularly among some sections of the Civil Service, but more because the demand for their services is growing ; although well-qualified persons are in short supply. The conference, she said, had the practical aim of inviting support for certain resolutions included in the draft report. This document had been prepared against the background of the report of the Clapham Committee on "Provision for Social and Economic Research", which was considered by many competent to judge as altogether too timid in its recommendations. She thought the national situation was such as to demand a much more vigorous approach to the whole problem of placing the social sciences upon a sound footing.

Prof. Gordon Childe illustrated the development of the social sciences by briefly sketching the history of anthropology, drawing a parallel with the growth of natural science; in both cases theory and practice had been closely interwoven. In the eighteenth and nineteenth centuries, traders, travellers, missionaries and Government representatives had begun to have direct dealings with primitive peoples in Africa, North America, the Pacific and other far-flung areas. Generally speaking, in spite of good intentions they were seriously handicapped in the concepts at their disposal, which had been assis uilated in their own society. A theoretical basis for the understanding of other cultures was lacking. For example, they tended to assume that ownership of land everywhere conformed to the canons of Roman law. Their methods were thus as unscientific as primitive efforts to control the wind by appealing to a 'wind god', and injustice and administrative difficulties were the result. Nevertheless, the accumulated descriptions of primitive customs were suitable as data for scientific study and led to the discovery of new facts.

Both in Great Britain and in the United States the theoretical background of early anthropologists had been borrowed from the idea of evolution in the form of Lamarckism. To Tylor, Taylor, Morgan and others, property under capitalism and Christian marriage seemed to be the culminating forms of these institutions. The new study of prehistoric archæology arose out of the rectification of the theory of unilateral evolution which had long been a stumbling-block. Prof. Childe remarked that the inadequacy of early anthropological theory no more means that social science is impossible than the exposure of the phlogis. ton theory disproved the existence of chemical science.

In commenting on the proposed report, he pressed the need for 'pure' research to proceed side by side with the application of its results, and with this end in view financial provision should be forthcoming, new academic chairs and other posts created in the right numbers, and ample opportunities for work in Government service. Early students of anthropology, like their colleagues in the natural sciences, were men of leisure and private means, a source of supply which has run dry. The first academic anthropologists were drawn from other disciplines or from the ranks of ndministrators or retired Civil servants. Although this first generation was somewhat sterile in matters of theory, it produced students trained to observe primitive life, who returned from their field experience equipped with new interpretations. Anthropology had advanced in response to social needs. Prof. Childe referred in passing to the Euclidean methodology of academic economics, a subject which, like anthropology, has been lately regenerated by the infusion of the results of realistic experience.

The Clapham Report he thought rather out of date in its outlook, particularly in the modesty of its claims, which was due to a pessimistic view of the availability of qualified personnel. Reluctance to expand on these grounds, while admitting the need for new posts, sets up a vicious circle. Nor did he agree with the Clapham Committee's view that social scientists do not need expensive apparatus for research ; their demands, he believed, are comparable with those of natural scientists, though their "laboratories' may be sited overseas.

Prof. J. D. Bernal, in opening the discussion, said that the draft report was admirable in the way it set out the role of the social sciences as experimental disciplines; but it needed strengthening and extending in certain particulars. The report dealt with the internal position in these subjects and not with their link with the natural sciences. Like Prof. Childe, he singled out economics for special comment. Economists, he suggested, regard materials and technique as constant factors, while taking prices, market trends and interest rates as variables, whereas natural scientists take the reverse position. In fact, both sets of factors are variables. Hence the need for multidisciplined research teams, which could be most useful in relation to present economic difficulties. A more 
immediate return could usually be expected from social than from natural science, inasmuch as the improvement of incentives, morale and organisation involved less delay and less dislocation than competition for capital goods. Experiments in social science, Prof. Bernal agreed, are costly, and he referred to the experimental houses now being studied by the Ministry of Works. The whole sociological investigation may cost a million pounds before it is finished. It may also happen, as sometimes occurs in the natural sciences, that a large-scale inquiry fails.

Prof. Bermal also agreed that it is urgently necessary to create senior posts in the social sciences, even if the available candidates have not attained eminence or maturity of years. In the early nineteenth century it was not usually decided to leave university chairs of science vacant rather than appoint persons who had not yet achieved fame. For example, Hamilton became professor of physics at Dublin at the age of twenty-two. If this practice were followed in the social sciences, the whole level of activity in the field might be raised. In any event, Prof. Bernal was doubtful whether so-called 'maturity of judgment' is an essential condition for success as a social scientist.

Prof. Bernal pointed to the value of regionalization in social science, by which he means the cultivation of local surveys in which people living in the area participate. Every area should have a team of social and natural scientists for this work, and out of this would come that co-operation between observer and observed which is so vital in social science. Indeed, this distinction might better be obliterated altogether.

Subsequent speakers expressed sympathy with the substance of the draft report and its recommendations, subject to certain amendments.

Prof. T. H. Marshall thought that the inadequacy of the financial need as assessed by the Clapham Committee is now fully recognized, and it would be a pity if the new report were committed to a definite figure. Grants should not be confined to universities ; Government departments, research institutes and voluntary bodies concerned with social services or the development of techniques also need support. He felt that the position of sociology in the universities is extremely serious, facilities for study or research being virtually non-existent. The invariable difficulty of deciding on an occupant for a chair could be dealt with as suggested by Prof. Bernal.

Prof. Marshall argued in favour of permanent social research or survey units at universities, providing for some posts which do not carry teaching duties. The factor of size of the institution should also be examined. In a large institution, administrative and supervisory burdens are so great that they prevent the professor from getting on with his proper work. The solution is to be found in creating more senior posts and in delegating much of the teaching.

The plea for more senior posts in the universities was strongly supported by Dr. M. Fortes and several other speakers, without fear of suitable persons not being available. Dr. Fortes also compared standards. It seemed to him that at Oxford it is possible to win a higher degree in physical science by the patient manipulation of instruments without the investment of much thought; but in the social sciences the path is more difficult. The order of priority in the estab. lishment of new university appointments in the various social sciences should, he felt, be carefully scrutinized and also the location of posts in areas where particular types of inquiry could most profitably be pursued.

The practice of the Royal Society in not admitting social scientists to membership received adverse comment. It is absurd, one speaker suggested, for ancient religious and political prejudices to determine limits of this kind; but speedy change of policy is unlikely, since the last reform of the Royal Society, initiated in 1833, has not yet been fully achieved.

A proposal in the draft report envisages an organisation of the same type as the Medical and Agricultural Research Councils, with advisory panels the chief function of which would be to stimulate research through the distribution of funds. Objections to this proposal were of two kinds : first, that a body might result interested in welfare to the exclusion of research, and second, in the absence of an independent body such as the Royal Society, social research would become dominated by Government control with all the possible ensuing dangers. Prof. Bernal believes that something of the kind is certainly needed if only to establish the intrinsic importance of the field, and he suggested that two bodies, one official and one independent, might serve the purpose. Another speaker favoured a council in the form of a 'federation' of social research units in Government departments and elsewhere. The most notable omission from the Clapham Report, he said, was the failure to recommend the setting up of social research units in Government departments like the Ministries of Labour, Health, and others primarily concerned with human organisation and relations. This would not preolude the use of mixed research teams when necessary. A social science research council, if formed, should be rooted in research units of this type as a condition of its success. It was eventually agreed to refer back for further clarification the whole section dealing with the proposal for a social science research council.

Mr. R. Innes, general secretary of the Association of Scientific Workers, said that the Association has always supported the idea of the unity of all branches of science in respect of their common interests and problems. It therefore welcomed the initiative displayed in preparing the report, and the executive committee had approved the recommendations in principle. The draft report had been circulated for comment to some 250 persons known to be active in the field. When the revised document was printed, the widest discussion would be needed wherever the possibility existed of implementing the recommenda. tions. In these discussions natural scientists should take part, for they did not always fully appreciate the significance of the work of their colleagues. It was the hope of the Social Sciences' Committee that those present as well as others would help to imple. ment the recommendations at universities and elsewhere. The Social Sciences' Committee would try to take a leading part in this. $\mathrm{He}$ added that a survey is in preparation of the fields of work, methods of training and career prospects in the social sciences.

Finally, the Conference adopted fe ur resolutions : (i) urging publication of the report; (ii) supporting in general its recommendations; (iii) inviting the Association to support all steps leading to implementation; and (iv) requesting the Association to submit the report for the consideration of the Lord President of the Council, the Minister for Economic Affairs, the University Grants' Committee, the Vice-Chancellors' Committee and other individuals and organisations concerned. 